\title{
ECONOMIC, SOCIAL AND CULTURAL RIGHTS DURING CRISIS IN CYPRUS: THE INTERPLAY BETWEEN DOMESTIC AND EXTERNAL NORMATIVE SYSTEMS
}

\author{
Constantinos Kombos* \\ Department of Law, University of Cyprus, Nicosia, Cyprus \\ c.c.kombos@ucy.ac.cy \\ Athena Herodotou** \\ Department of Law, University of Cyprus, Nicosia, Cyprus \\ herodotou.athina@ucy.ac.cy
}

Received: 4 February 2020 | Last Revised: 9 November 2020 | Accepted: 10 March 2021

\begin{abstract}
Economic, Social and Cultural (ESC) rights have been present and active in the Cypriot legal order from the moment of its constitutional genesis. Due to the special relationship between the Constitution and the European Convention on Human Rights (ECHR), the judiciary has adopted a unique approach when interpreting the Constitution; it has been willing to engage into a comparative juridical analysis and to rely on the ECHR and the findings of the European Convention on Human Rights (ECtHR). Through this nexus with the ECHR and the streamlined approach with the ECtHR, the legal system of Cyprus has been progressive in placing social and economic rights - and to a lesser extent cultural rights - in a secure position. This traditional approach of the Cypriot courts was called into question by the 2011-2016 economic crisis, which challenged the interplay between domestic and external normative systems. The aim of this paper is to assess the impact of the recent economic crisis on the protection of ESC rights and the change in the balance between domestic and normative systems. The analysis concludes that the protection of ESC rights under the Cypriot Constitution, as formed by Cypriot case law, has been substantive and effective, while positively influenced by the extensive deployment of the
\end{abstract}

* Associate Professor of Public Law and EU Law at the Department of Law, University of Cyprus, Nicosia, Cyprus.

** Researcher and PhD Candidate at the Department of Law, University of Cyprus, Nicosia, Cyprus. 
comparative method. That long-standing approach has been challenged by the economic crisis and it seems that the extrovert judicial viewpoint is now partly reconsidered. The Supreme Court has indicated, albeit in specific instances, its willingness to disregard guidance from external influences and to focus instead on the idea that national constitutional protection can and should exceed that of the ECHR.

Keywords: Cyprus, ECHR, Economic Crisis, Right to Property, Social and Cultural Rights.

\section{INTRODUCTION}

The 1948 Universal Declaration of Human Rights (UDHR) articulated, for the first time, civil, cultural, economic, political and social rights and freedoms for all human beings. However, the subsequent adoption of two separate, legally binding international covenants, the International Covenant on Civil and Political Rights (ICCPR) and the International Covenant on Economic, Social and Cultural Rights (ICESCR), gave rise to the debate on whether human rights are 'relative', 'universal' or 'relatively universal'.' The initial conception of economic, social and cultural rights (ESC rights) as positive rights, demanding State intervention and susceptible to the progressive realization through the use of all appropriate means, ${ }^{2}$ led to their description as 'second generation' rights. ${ }^{3}$ The persistence of this categorization of human rights into civil and political (i.e., the 'first generation' rights) and ESC was not only detrimental to the quality of the latter set of rights but also undermined the 'universality and practical implementation of all human rights'. ${ }^{4}$ However, this division does longer stands correct, and the international community has recognized that the two sets of human rights are 'universal, indivisible and interdependent and interrelated' and must be treated 'globally in a fair and equal manner, on the same footing, and with the same emphasis.' 5

\footnotetext{
See Manisuli Ssenyonjo, Economic, Social and Cultural Rights in International Law (Oxford: Hart, 2009), 4.

ICESCR, Article 2; UN Committee on Economic, Social and Cultural Rights, General Comment No. 2: International technical assistance measures (Art. 22 of the Covenant), 2 February 1990, E/1990/23.

3 Karel Vašák, "A Thirty-Year Struggle: The Sustained Efforts to Give Force of Law to The Universal Declaration of Human Rights," UNESCO Courier 11 (1977): 29-32.

4 Abdullahi Ahmed An-Na'im, "To Affirm the Full Human Rights Standing of Economic, Social and Cultural Rights," in Economic, Social and Cultural Rights in Practice: The Role of Judges in Implementing Economic, Social and Cultural Rights, eds. Yash P. Ghai, Jill Cottrell (London: Interights, 2004), 7.

5 UN General Assembly, Vienna Declaration and Programme of Action, 12 July 1993, A/CONF.157/23, para 5.
} 
This paper aims at assessing the impact of the recent economic crisis in Cyprus on the protection of ESC rights and the interplay of domestic and external normative systems. In terms of structure, the second part of this paper determines the status of ESC rights in the Cypriot legal order and ascertains their secure position from the moment of the genesis of the Constitution, with an effective and progressive human rights structure that safeguards the respect for and protection of ESC rights. Unfortunately, this statement does not hold true in relation to the right to take part in cultural life, as the Constitution fails to recognize the cultural rights of any other group other than the Greek-Cypriot and Turkish-Cypriot communities. The third part then examines the content of the ESC rights protected under the Cypriot Constitution, in light of Cypriot case law. This part demonstrates the traditional willingness of the judiciary to engage in a comparative juridical analysis and to rely on external influences, in order to safeguard ESC rights. The final part then assesses the recent approach of the judiciary towards the protection of ESC rights following the exceptional economic crisis that devastated the Cypriot economy.

The unprecedented bail-in and the strict conditionality imposed by international lenders had a negative impact on economic and social rights, with substantial social protection cuts and reforms. Recent case law indicates the focus of jurisprudence was placed solely on the salaries, pensions and benefits of employees and pensioners of the public and wider public sector, despite the detrimental effects of the crisis on the private sector as well. Nevertheless, the existing case law suggests that the judiciary focused on the right to property and, notwithstanding the initial failure to protect the said right, the Cypriot courts went beyond their traditional approach by disregarding guidance from other external influences and by developing their own understanding for the benefit of human rights protection.

Specifically, the Cypriot courts had to decide two intertwined issues. First, whether the salaries, pensions and benefits of employees and pensioners of the public and wider public sector are protected under Article 23 of the Constitution and Article 1 of the First Protocol to the ECHR (protecting the right to property). 
Second, whether the limitation of such rights on the ground of public interest is compatible with the said normative provisions. Cypriot courts found that the right of property, as envisaged in the Constitution, is afforded greater protection than that of Article 1 of the First Protocol to the ECHR. This is the case because the limitations imposed by the former provision are stricter than the latter; consequently, limitations on the ground of public interest that may be compatible with the First Protocol, are incompatible with the Constitution and thus the relevant legislation is unconstitutional. It is therefore submitted that the Cypriot courts endorsed a new rights-based approach centred on the idea that national constitutional protection can and should exceed that of other external influences. ${ }^{6}$ It is further submitted that this approach is also in line with the Cypriot courts' constitutional duty not to subject the fundamental rights and liberties found in the Constitution to any other limitations or restrictions than those provided therein and with their international obligation under Article 53 of the ECHR not to interpret the instrument in such a way as to limit or derogate from any of the fundamental rights and freedoms which may be ensured under the laws of the contracting parties.

\section{ESC RIGHTS IN THE CYPRIOT LEGAL ORDER}

\subsection{The Genesis of the Constitution and the Inclusion of ESC Rights}

The Republic of Cyprus was established as an independent and sovereign State on 16 August 1960. The 196o Constitution established a unitary yet bicommunal State, comprised of the Greek-Cypriot and the Turkish-Cypriot communities. The Constitution has been described as 'probably the most rigid', 'the most detailed' and 'the most complicated' in the world, ${ }^{7}$ due to its historical origin and bi-communal character. ${ }^{8}$ Despite this general

\footnotetext{
6 For a general assessment of the constitutional effects of the economic crisis, see Constantinos Kombos, "Constitutional Review and the Economic Crisis: In the Courts We Trust?" European Public Law 25, no. 1 (2019): 105-133; Constantinos Kombos, "Constitutional Review and the Economic Crisis: In the Courts We Trust? - Part Two," European Public Law 25, no. 2 (2019): 229-248.

Stanley Alexander De Smith, The New Commonwealth and Its Constitutions (London: Stevens, 1964), 285.

8 Regarding the history, nature and idiosyncrasies of the Constitution of Cyprus, see generally Criton C. Tornaritis, Cyprus and its Constitutional and Other Problems (Nicosia, 1980), 43-66.
} 
constitutional complexity, the provisions on human rights enshrined in Part II of the Constitution (Articles 6-35) constitute a notable exception by adopting clear and comprehensive provisions. ${ }^{9}$

Specifically, the 1960 Constitution of Cyprus followed the example of many post-war constitutions and adopted a holistic approach by guaranteeing not only civil and political rights but also ESC rights ${ }^{10}$ exercised within the framework of public interest and the common good." It must be pointed out that the Constitution does not endorse a specific economic, social or political ideology. It adopts a neutral position by striking a careful balance between liberalism (e.g., with freedom of choice for engaging in the individual's preferred commercial and professional activities) and protectionism (e.g., by providing a safety net to maintain social cohesion and equalitarian justice). ${ }^{12}$

\subsection{International protection of ESC Rights in the Cypriot Legal Order}

In addition to the constitutional human rights protection, Cyprus has ratified several international human rights treaties. Upon their necessary ratification pursuant to Article 169 of the Constitution, international treaties obtain an elevated status that gives them priority over ordinary domestic laws, but not over the Constitution. ${ }^{13}$ Subsequently, if a national court identifies an inconsistency between any domestic law and a ratified international treaty, it is obliged to refuse to implement the former. ${ }^{14}$

The most influential human rights instrument in the Cypriot legal order is undoubtedly the European Convention on Human Rights (ECHR), ratified in 1962. This influence may be attributed to the fact that Articles 2-14 of the ECHR and its First Protocol served as the prototypes for drafting Part

9 Constantinos Kombos, "Social Rights in the Republic of Cyprus," in Social and Economic Rights as Fundamental Rights, ed. Krzysztof Wojtyczek (Utrecht: Eleven International Publishing, 2016), 60.

10 See Kontos v Republic (1974) 3 CLR 112; Apostolou a.o v Republic (1984) 3 CLR 509; Hadjisavva v Republic (1972) 3 CLR 174 .

11 Criton C. Tornaritis, "The Social and Economic Rights Under the Law of the Republic of Cyprus," in Mélanges Marcel Bridel (Lausanne, 1968), 2.

12 Kombos, "Social Rights in the Republic of Cyprus," 61.

13 See Kantara Shipping Limited v Republic (1971) 3 CLR 176.

14 Alecos Markides, "The Republic of Cyprus," in Constitutional Law of 10 EU Member States: The 2004 Enlargement, eds. Kortmann, C. et al., (Deventer: Kluwer, 2006), I-63. 
II of the Constitution. ${ }^{15}$ As a result, Cypriot courts turn to the interpretation of the ECHR provisions given by the European Court of Human Rights (ECtHR) not only when interpreting the ECHR, but also when interpreting the corresponding constitutional provisions. ${ }^{16}$

Additionally, Cyprus ratified the European Social Charter. However, it has not ratified the whole Charter and has yet to ratify a number of important provisions. Contrary to the judicial approach towards the ECHR and the ECtHR, and despite being a party to the Charter since 1967, Cypriot courts failed to adequately develop jurisprudence based on the European Social Charter or the relevant decisions of the European Committee of Social Rights. However, in the limited case law of the Cypriot courts dealing with the Economic Social Charter, it was recognized that "by the ratification of the European Social Charter a duty is imposed upon the contracting States to take steps for the implementation of such provisions". ${ }^{17}$

On a universal level, Cyprus ratified the ICCPR, along with its two optional protocols, and the ICESCR. Unfortunately, Cyprus has not yet signed the 2013 Optional Protocol to the ICESCR. Moreover, concerning labour law and worker rights, the International Labour Organization (ILO) has influenced the Cypriot legal order to a great extent. Specifically, Cyprus is a member of the ILO and has ratified 57 conventions and four protocols, including all eight fundamental conventions of the ILO.

It should be mentioned that in 2004 Cyprus acceded to the European Union (EU). Consequently, human rights in Cyprus are also protected under the Charter of Fundamental Rights of the EU, which is legally binding on all member States when implementing EU law, by virtue of the Treaty of Lisbon. ${ }^{18}$ Consequently, human rights in Cyprus receive the protection of

15 See Article 5 of the Treaty concerning the Establishment of the Republic of Cyprus between the United Kingdom, Greece, Turkey and Cyprus, Cmnd 1252; UNTS vol. 382, 16 August 1960.

16 Constantinos Kombos, The Impact of EU Law on Cypriot Public Law (Athens: Sakkoulas, 2015), 38-46; Achilles C. Emilianides, Constitutional Law in Cyprus (Alphen aan der Rijn: Wolter Kluwer Law and Business, 2013 ), 149. See also, Fourri a.o v Republic (1980) 2 CLR 152; Costa v Republic (1982) 2 CLR 120; Cyprus Sulphur and Copper Company Ltd a.o. v Pararlama Ltd (1990) 1 CLR 1051.

17 Demetriou a.o. v Republic (1985) 3 CLR 1853.

18 Machteld Inge van Dooren, "The European Union and Human Rights: Past, Present, Future," Utrecht Journal of International and European Law 26, no. 70 (2009): 47-52; Tawhida Ahmed, Israel de Jesús Butler, "The European 
the supreme law of the Republic, the Constitution, which should be in accordance with EU law.19

\section{ESC RIGHTS UNDER THE CYPRIOT CONSTITUTION: THE TRADITIONAL JUDICIAL APPROACH}

\subsection{ESC Rights Protected under the Constitution of Cyprus}

The Constitution of Cyprus provides for several ESC rights, beyond civil and political rights. These ESC rights include the right to a decent existence and social security (Article 9), the right to free education (Article 20), the right to form and join trade unions (Article 21(2)), the right to property (Article 23), the right to practice any profession or to carry on business (Article 25) and the right to strike (Article 27). Moreover, it is submitted that the right to take part in cultural life is indirectly recognized by the Constitution, but only for the Greek-Cypriot and Turkish-Cypriot communities. The following analysis aims at exemplifying the influence of external normative systems to the interpretation of the constitutionally protected ESC rights.

\subsubsection{The Right to a Decent Existence and Social Security}

Article 9 of the Constitution provides that "[e]very person has the right to a decent existence and to social security. A law shall provide for the protection of the workers, assistance to the poor and for a system of social insurance". The reference to 'decent existence', rather than, for instance, to the more usual 'adequate standard of living', is relatively unique. Article 9 may be characterized as the backbone of the social policy of the State and as cardinal for the establishment of a social welfare system with a relatively dense social safety net. The Supreme Court held that "Article 9 has the effect of placing social rights on an equal footing with political rights, both fundamental under the Cyprus Constitution, as well as the [UDHR]". ${ }^{\circ}$

Union and Human Rights: An International Law Perspective," European Journal of International Law 17, no. 4 (2006): 771-801; Sionaidh Douglas-Scott, "The European Union and Human Rights after the Treaty of Lisbon," Human Rights Law Review 11, no. 4 (2011): 645-682.

19 Constitution of Cyprus, Article 179.

20 Apostolides a.o. v Republic (1982) 3 CLR 928. 
In order to fulfil its obligations under Article 9, Cyprus enacted the 2010 Social Insurance Law, regulating the Cypriot social protection scheme, and providing a number of benefits. ${ }^{21}$ In terms of social assistance, the guaranteed minimum income (GMI) scheme was introduced in 2014 in the Cypriot legal order. ${ }^{22}$ Other laws further provide for family allowances, ${ }^{23}$ whereas the general health system (GHS) introduced in 2017 offers healthcare services to all persons who live in the areas controlled by the Republic. ${ }^{24}$

The relevant case law suggests that Article 9 creates substantive obligations and has a justiciable and autonomous nature. ${ }^{25}$ However, the fulfilment of these substantive obligations can only be judicially scrutinised after State organs undertake action in order to attempt to comply with the said provision. ${ }^{26}$ Therefore, there can be no in abstracto judicial intervention; compliance with Article 9 can only be made in the specific context that a legislative act had created and on a case-by-case basis. ${ }^{27}$ In this sense, Article 9 does not establish an actionable right for the provision of benefits that would bring about an adequate standard of decent existence. ${ }^{28}$

Article 9 is a partial reflection of Article 25(1) of the UDHR. Comparing the two texts, it is evident that the Cypriot Constitution fails to provide a definition of 'decent existence' or at least a measuring criterion. Is 'decent existence and social security' a synonym of 'adequate standard of living'? Does the former include the right to food, water, clothing, health or housing, similar to the latter? The Cypriot courts have not elaborated on a definition of 'decent existence'. Tornaritis argues that Article 9 generates an obligation to "create and maintain such conditions of living, of work

The Social Insurance Law (59(I)/2010), as amended.

22 Guaranteed Minimum Income and Social Benefits Law (109(I)/2014), as amended.

23 For instance, there are the marriage grant, birth grant, funeral grant, maternity allowance, child allowance, single-parent allowance, student grant, mother allowance and financial assistance to multi-child families.

24 See General Healthcare System (Amending) Law (74(I)/2017).

25 Papaphilippou v Republic (1960-1961) 1 RSCC 62.

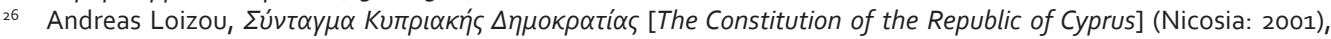
50-51. See also, Katsaras a.o. v Republic (1973) 3 CLR 145, Pelidi a.o v Republic, Recourse Nos. $1650 / 1999$ and 789/2000, 15 June 2001; Hadjisavva v Republic (2006) 4 CLR 677; Kaoulas v Republic, Case No. 407/2009, 18 March 2011.

27 Kombos, "Social Rights in the Republic of Cyprus," 64-6.

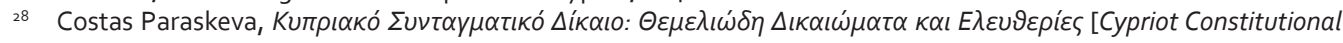
Law: Fundamental Rights and Liberties] (Athens: Nomiki Vivliothiki, 2015), 116-7. 
and of health as to enable every person to enjoy a standard of living adequate for the health and well-being of himself and his family". ${ }^{29}$ This interpretation is supported by the second clause of Article 9 laying down practical steps for the implementation of this right; i.e., passing legislation for the protection of a specific class of beneficiaries (i.e., workers), for the assistance of the poor (without defining the composition of that class or the criterion for it), and for the establishment of a social insurance system. Indeed, Article 9 can be interpreted as having an umbrella effect, thus protecting the rights to health, food, housing and water, which are essential for safeguarding a person's decent living, , $^{30}$ despite the absence of their direct reference in the Constitution.

\subsubsection{The Right to Education}

Article 20 of the Constitution safeguards the right to free and compulsory primary education. ${ }^{31}$ However, this right is subject to those formalities, conditions or restrictions that are necessary and are based on grounds set out in Article 20(1). It is noteworthy that the Cypriot Constitution affords broad and extensive protection, especially in comparison to corresponding Article 2 of the First Protocol to the ECHR.

Case law indicates that parents are under an obligation to take all necessary measures to safeguard the continuous education of their children; any omission by the parents entails their liability, as such education is obligatory under Article 20 of the Constitution, as well as Article 28 of the on the Rights of the Child..$^{32}$ Additionally, the right to education refers to the liberty of parents to choose between public and private education for their children, not to the right to choose the specific public school they will attend, which is in accordance with Articles 9 of the ECHR and Article 13 of the ICESCR. 33

\footnotetext{
Tornaritis, The Social and Economic Rights. See also Emilianides, Constitutional Law in Cyprus, 174. For a detailed analysis of Article 9, see Kombos, "Social Rights in the Republic of Cyprus," 62-6. See Constantinides v Republic (1967) 3 CLR 483.

Karagiorgi v Papadopoulou, App. No. 153/2009, 25 September 2009.

Theodoulidou v Republic (1989) 3 CLR 2605.
} 
In Kallenou v Republic, the Court relied on Article 20 of the Constitution, as well as Article 2 First Protocol to the ECHR and Article 13 of the ICESCR, and concluded that the State may impose the necessary restrictions in the interest of ensuring the quality of the education, provided that the essence of the right is not nullified. ${ }^{34}$ Similarly, in Alpha and the Omega Evangelical Educational Foundation Ltd v Republic, the Supreme Court held that legislative measures setting the level of tuition fees for private schools, may be implemented for protecting public interests, the rights of others and the quality of the right to education. ${ }^{35}$ What was interesting in this case, was the Court's reference to Article 2 of the Protocol to the ECHR, the ECtHR's Belgian Linguistic case and Article 13(3) ICESCR for reaching its decision.

In conclusion, Article 20 has been affected by external influences and has a dual effect; on the one hand, it establishes a social duty for individuals for compulsory education and, on the other hand, it creates a responsibility for the State to safeguard the quality and unrestricted substantive access to educational facilities on the island. ${ }^{36}$

\subsubsection{The Right to Join Trade Unions}

The right to form and to join trade unions is explicitly protected under Article 21(2) of the Constitution, in the context of the right to freedom of peaceful assembly and association with others. No person shall be compelled to join any association or to continue to be a member, as Article 21(2) protects both the right to join, as well as the right not to join a trade union, placing emphasis on free choice as a higher value than that embedded in organized action in the form of trade union membership. ${ }^{37}$ Moreover, the existence and the proper and unhindered functioning of trade unions of civil servants is also protected under this provision..$^{8}$

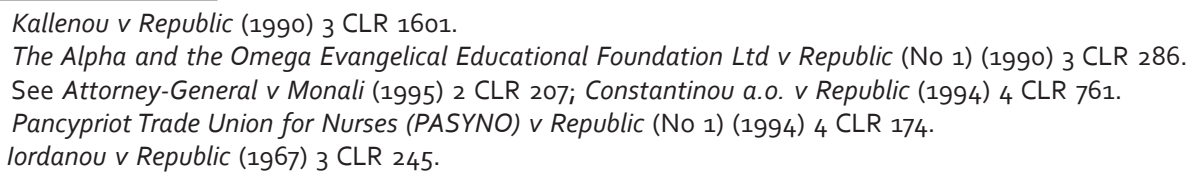


Additionally, the Supreme Court stressed an imposed "syndicat unique obligatoire" (compulsory single union) should be avoided and that there should exist a guarantee for the "pluralisme syndical" (trade union pluralism). 39 The Court paralleled again the protection afforded by the Constitution to the protection under the ECHR, specifically Article 11(1), and the relevant ECtHR case law. ${ }^{40}$ Finally, Article 21(2) has also been influenced by other external normative systems, beyond the ECHR. In Cypriot Shipowners Union case, the Supreme Court noted that Article 21(2) should be interpreted in the light of the ratified international conventions, such as Article 8 ICESCR, Article 22 ICCPR, Article 11 ECHR and Articles 14 and 15 ILO Convention No. $87 \cdot^{41}$

\subsubsection{The Right to Work}

As already mentioned above, the protection of workers is regulated under Article 9 of the Constitution. In addition, Article 25 further safeguards the right of every person to practice any profession or to conduct any trade or business and enables the individual to take a direct part in social life, without arbitrary interference from State power. Article 25(2), however, sets formalities, conditions and restrictions on such free selection of profession and business, with the State reserving the power to regulate it in the interests of others and of the general public. Such limitations must be theme specific and cannot be based on a generalized intention to safeguard public interest at large. ${ }^{42}$

\subsubsection{The Right to Strike}

Article 27 of the Constitution explicitly recognizes and guarantees the right to strike as a fundamental, inalienable and autonomous human right, the core of which cannot be negated. ${ }^{33}$ In Organisation of Crushed

39 Iordanou $v$ Republic (1967) 3 CLR 245.

40 National Union of Belgian Police v Belgium, Merits, just satisfaction, App No 4464/70 (A/19), (1979-80) 1 EHRR 578; Swedish Engine Drivers' Union v Sweden, Judgment, Merits, App No 5614/72 (A/20), [1976] ECHR 2.

${ }_{41}$ Cypriot Shipowners Union a.o. v Registrar of Trade Union a.o. (1988) 3 C.L.R. 457.

42 Tornaritis, Cyprus and its Constitutional, 13.

43 Sidiropoulos a.o. v Ship "Panagia Myrtidiotissa" (1987) 1 CLR 564, 573; Panagia Myrtidiotissa (the ship) v Sidiropoulou a.o. (1998) 1 CLR 1000, 1012-1013. 
Stone case, the Supreme Court drew guidance from a number of external sources $^{44}$ and interpreted the concept of 'strike' as the workers' collective abstention from their duties, with the aim of exercising pressure, primarily to their employers, in order to safeguard and promote their collective interests. ${ }^{45}$ Nevertheless, the right to strike is not absolute but may be regulated by law for those grounds set out in Article 27(2). Yet, no such law has been promulgated. Limitations are incidentally imposed via a number of legislative acts ${ }^{46}$ whereas other laws impose certain conditions that must be met in order to call a lawful strike. ${ }^{47}$ Members of the armed forces, the police and the long-defunct gendarmerie are prohibited from resorting to strike action. ${ }^{4}$

The Constitution explicitly safeguards the right to strike. Nevertheless, this right is closely intertwined with the freedom of speech and expression (Article 19 of the Constitution) and the freedom of peaceful assembly (Article 21 of the Constitution), as they ensure the effective protection of worker and trade union rights. ${ }^{49}$ It can be argued that the right to strike is also connected with Article 9 of the Constitution, imposing a substantive and positive obligation to the State to offer legislative protection to workers. ${ }^{50}$

\subsubsection{The Right to Take Part in Cultural Life}

Beyond the right to education, which is essentially a cultural right, the Cypriot Constitution contains no specific provisions expressly protecting the right to participate in cultural life. Nevertheless, it may be argued that the respect and protection of such rights are - to some extent inherent in the Constitution, but only in relation to the Greek-Cypriot

\footnotetext{
44 The Court drew from the Greek Constitution and jurisprudence, Halsbury's Laws of England, Article 6 European Social Charter and Article 8 ICESCR.

45 Organisation of Crushed Stone and Sand Industrialists v Protection of Competition Commission (1992) 4 CLR 711, 718-722.

46 See, for instance, Criminal Code, Article 64 (Cap. 154).

47 See, for instance, Trade Union Law, Annex I, Article 14(d) (by virtue of Article 18) (Law No. 71/1965) and Civil Aviation Law, Article 4(6) (Law No. 213(I)/2002).

48 Constitution of Cyprus, Article 27(2). See also, Police Law, Article 55 (Law No. 73(I)/2004).

49 Paraskeva, Cypriot Constitutional Law, 441.

5o See further Kombos, "Social Rights in the Republic of Cyprus," 62-6; Tornaritis, The Social and Economic Rights.
} 
and Turkish-Cypriot communities. Particularly, the Constitution is based on bi-communalism and recognizes the Greek community (comprising all citizens of the Republic who are of Greek origin and whose mother tongue is Greek or who share Greek cultural traditions or who are members of the Greek-Orthodox Church) and the Turkish community (comprising all citizens of the Republic who are of Turkish origin and whose mother tongue is Turkish or who share Turkish cultural traditions or who are Muslims)..$^{51}$ Due to the need for coexistence between these two different cultural traditions, the Constitution does not regulate their cultural rights, but delegates to the Greek and the Turkish Communal Chambers the competence to exercise legislative power in relation to all educational, cultural and teaching matters..$^{52}$ Following the suspension of the operation of the Communal Chambers after the events of 1963-1964, cultural matters have been conferred to the Ministry of Education and Culture.

The Cypriot Constitution fails to recognize the right of groups other than Greek-Cypriots and Turkish-Cypriots to take part in cultural life. Specifically, while the Constitution recognizes the existence of only three minority groups (namely Armenians, Maronites and Latin Roman Catholics), these groups were obliged to associate themselves with one of the two communities on the island. ${ }^{53}$ This constitutionally rigid classification of all citizens into the two dominant communities violates international human rights standards ${ }^{54}$ and has been characterized as a violation of their cultural rights (i.e., the right of everyone to choose his or her own identity, the right to identify or not with one or several groups and to change that choice, and the right to participate or not participate in a given group).55

51 See Constitution of Cyprus, Article 2(1) and (2).

52 See Constitution of Cyprus, Article $87(1)(b)$.

53 See Constitution of Cyprus, Article 2(3).

54 See Committee on the Elimination of Racial Discrimination, Concluding observations on the $17^{\text {th }}-22^{\text {nd }}$ periodic reports of Cyprus, adopted by the Committee at its $83^{\text {rd }}$ session, UN Doc. CERD/C/CYP/CO/17-22, (23 September 2013) para. 14 .

55 See also, Council of Europe Advisory Committee on the Framework Convention for the Protection of National Minorities, Fourth opinion on Cyprus, Doc. ACFC/OP/IV(2015)001, (18 March 2015), paras. 11-5; Nikolas Kyriakou and Nurcan Kaya, "Minority rights: solutions to the Cyprus conflict," Minority Rights Group International, (2011). 
Notwithstanding the above, cultural rights may be incidentally protected through the freedom of movement (Article 13), freedom of thought, conscience and religion (Article 18), freedom of speech and expression (Article 19), the right to education (Article 20), freedom of peaceful assembly (Article 21) and the right to non-discrimination and equality before the law (Article 28)..$^{56}$

\subsection{The Right to Property: A Hybrid Right?}

The right to property poses a difficulty in its classification under the traditional dichotomy of civil and political rights and ESC rights. ${ }^{57}$ The intrinsic tension between the right to property as civil liberty and its social function can be seen in the negotiations of international human rights instruments. The right to property is explicitly protected under Article 17 of the UDHR, notwithstanding the controversy caused both prior and after its adoption..$^{8}$ The ICESCR and ICCPR, however, remain silent and do not safeguard the right. ${ }^{59}$ At the regional level, the right to property appears in Article 1 of the First Protocol to the ECHR and Article 17 of the Charter of Fundamental Rights of the EU. The social function of the right to property is increasingly recognized by regional bodies as a means of survival, advancing the rights to food, housing and social security. ${ }^{60}$

Turning now to the Cypriot legal order, the right to property is safeguarded by Article 23 of the Constitution, consisting of 11 paragraphs. Article 23(1) stipulates that "[e]very person, alone or jointly with others, has the right to

${ }_{56}$ Report of the Special Rapporteur in the field of cultural rights on her mission to Cyprus, UN Doc. A/HRC/34/56/ Add.1, (2 March 2017), para. 8.

57 On the duality of the right to property, see Allan Rosas, "Property Rights," in The Strength of Diversity: Human Rights and Pluralist Democracy, eds. Allan Rosas, Jane Helgesen and Diane Goodman (The Hague: Martinus Nijhoff, 1992), 133-157.

$5^{8}$ See Gudmundur Alfredsson, "Article 17" in The Universal Declaration of Human Rights: A Commentary, eds. Eide, A et al. (Oslo: Scandinavian University Press, 1993), 255-262. See also, Catarina Krause and Gudmundur Alfredsson, "Article 17," in The Universal Declaration of Human Rights: A Common Standard of Achievement, eds. Gudmundur Alfredsson and Asbjørn Eide (The Hague: Martinus Nijhoff, 1999), 359-378.

59 Note however that property appears in Article 2(1) ICCPR and Article 2(2) ICESCR as part of the non-discrimination clause.

60 See Christophe Golay and loana Cismas, Legal Opinion: The Right to Property from a Human Rights Perspective (Montreal: Rights and Democracy, 2010). See also, Rhoda E. Howard-Hassmann, "Reconsidering the Right to Own Property," Journal of Human Rights 12, no. 2 (2013): 180-197. 
acquire own, possess, enjoy or dispose of any movable or immovable property and has the right to respect for such right". However, the constitutionally protected right to property is not absolute. Article 23(2) prohibits deprivations, restrictions or limitations of the right, except those provided for in Article 23(3). Accordingly, deprivations, restrictions or limitations are lawful when they are imposed by law and are absolutely necessary for the interest of the public safety or the public health or the public morals or the town and country planning or the development and utilization of any property to the promotion of the public benefit or for the protection of the rights of others.

The rest of the provisions of Article 23 regulate issues of compulsory acquisition and requisition, which gave rise to rich and extensive case law, ${ }^{61}$ as well as matters of vakf (waqf) movable or immovable property and the movable and immovable property belonging to the episcopal see, monastery, church or any other ecclesiastical corporation. ${ }^{62}$ The economic crisis brought the first three paragraphs of Article 23 to the forefront of human rights protection against the numerous cuts and reforms introduced by the State in order to meet strict conditionality requirements and secure timely lending. Specifically, the Cypriot courts used the right to property to bypass the pragmatist emergency approach in favour of a rights-based approach, through the strict adherence to the national constitutional protection of the right, which exceeds that of other international instruments.

\section{PROTECTING ESC RIGHTS IN THE POST-CRISIS ERA: TOWARDS A NEW RIGHTS-BASED APPROACH?}

\subsection{The Background of the Economic Crisis and the Unprecedented Bail-In}

Cyprus acceded to the European Monetary Union in 2008. The first signs of recession of the Cypriot banking sector appeared in 2009; however, the government failed to take measures necessary to prevent the crisis or to

${ }_{61}$ See for instance, Stavridi a.o. v Republic (1992) 3 CLR 303, Karaolis v Ministry of Interior (2004) 3 CLR 76.

62 See, for instance, Holy Temple of Chryseleousis Strovolou v Republic (1989) 3 CLR 3074; Holy Bishopric Paphos v Republic (1987) 3 CLR 1371. 
prepare for the danger. By 2011, Cyprus was unable to maintain fiscal stability, and by June 2012, the government submitted a request for stability support to the European Stability Mechanism (ESM) and the International Monetary Fund (IMF). On 16 March 2013, the Eurogroup agreed to an unprecedented ‘bail-in' for €10 billion.

According to the agreement, the ESM and IMF would provide financial assistance to Cyprus, but the amount could not be used for the needed recapitalization of the two largest banks on the island (Laiki Bank and Bank of Cyprus), which was estimated at $€ 5.8$ billion. Cyprus would have to recapitalize them using its own means. Specifically, and according to the agreement, Laiki Bank would have to be dissolved, levying all uninsured deposits (i.e., deposits larger than $€ 100,000$ ), ${ }^{63}$ whereas $47.5 \%$ of uninsured deposits in the Bank of Cyprus would also have to be levied. ${ }^{64}$ In this manner, the small-scaled Cypriot economy was viewed as the ideal opportunity to depart from the established practice of bailouts and use 'bail-in' as a new EU banking resolution tool, with minimal contagion capacity in the event of failure.

\subsection{The Influence of the Economic Crisis on ESC Rights}

On 30 April 2013, the House of Representatives implemented the Memorandum of Understanding on Specific Economic Policy Conditionality (MoU) into legislation subjecting Cyprus to strict conditionality. ${ }^{65}$ According to the MoU, Cyprus had to undertake profound changes in its economic and social policies and to implement significant structural reforms to support its fiscal consolidation efforts. Significant cuts were introduced in public finances, as well as in social benefits, thus affecting social security schemes, pensions, healthcare and public assistance.

63 On the issue of insured deposits, see Directives 94/19/EC of the European Parliament and of the Council of 30 May 1994 on deposit-guarantee schemes and 2009/14/EC of the European Parliament and of the Council of 11 March 2009 amending Directive 94/19/EC on deposit-guarantee schemes as regards the coverage level and the payout delay.

64 The bail-in was based on Decrees Nos. 103 and 104 of 29 March 2013, adopted by the Central Bank of Cyprus, acting as the Resolution Authority.

65 The MoU was ratified by the House of Representatives with Financial Assistance Facility Agreement (Ratifying) Law (1(III)/2013). 
Indicatively, and in relation to old-age benefits, legislation introduced scaled reductions in statutory pensions, stricter eligibility conditions and provided for automatic adjustment of the statutory retirement age every five years. ${ }^{66}$ The government employees' pension scheme (GEPS) was also affected by the various reform initiatives with, for instance, the increase of the contribution rate for the GEPS. Moreover, the 2014 introduction of the GMI scheme led to a dramatic fall in the number of eligible beneficiaries of social assistance, mostly attributed to the high rejection percentage (63\%) of the applications due to assets and deposits that exceeded the statutory threshold. ${ }^{67}$

The cuts and reforms introduced as austerity measures had an impact on both the private and public sectors. And while one would expect that the constitutionality of these measures would have undergone judicial scrutiny by now, this is not the case. The following section of this paper assesses the approach of the Cypriot courts towards these cuts and reforms and their impact on ESC rights. ${ }^{68}$ However, two preliminary observations are in place: first, the economic crisis did not have an impact on cultural rights; thus, the discussion will focus on economic and social rights. Second, the relevant case law is primarily focused on Article 23 of the Constitution, and not Article 9 relating to decent existence and social security.

\subsection{Human Rights Protection in the Aftermath of an Unprecedented Crisis:}

\section{Developing a New Rights-Based Approach?}

The assessment of the legality of the social protection cuts and reforms adopted as austerity measures in Cyprus is relatively limited. The relevant case law relates mostly to the salaries, pensions and benefits of employees

66 See Social Insurance Law, as amended.

${ }_{67}$ Consideration of Reports: Reports Submitted by the States Parties in accordance with Articles 16 and 17 of the Covenant, Sixth periodic report of Cyprus (Doc. No. E/C.12/2016/SR.53), Committee on Economic, Social and Cultural Rights (59 $9^{\text {th }}$ session), 22 September 2016, para 33.

68 On the conceptual framework for dealing with socio-economic rights see David Bilchitz, "Socio-Economic Rights, Economic Crisis, and Legal Doctrine," International Journal of Constitutional Law 12, no. 3 (2014): 710-739. 
and pensioners of the public and wider public sector. ${ }^{69}$ What is interesting in the case of Cyprus, is the aforementioned tendency of the domestic courts to confine their reasoning to the violation of the right to property (Article 23 of the Constitution). Arguments brought before the courts in connection with breaches of other constitutionally protected rights were downplayed by the courts, having already found laws unconstitutional by virtue of Article 23. A rare exception to this is the first case decided in connection to the constitutionality of particular austerity measures, where the Court reached a peculiar and ambiguous result. This ambiguity exists to this day.

\subsubsection{The Right to Property under Judicial Scrutiny}

The only competent venue for examining the constitutionality of cuts and reforms in social protection benefits, salaries or pensions is the Administrative Court, via a recourse pursuant to Article 146 of the Constitution..$^{70}$ Particularly, the constitutionality of a law can be incidentally examined following a recourse against a decision, an act or omission of any organ, authority or person, exercising any executive or administrative authority, filed by people whose legitimate interests were adversely and directly affected by such reforms. ${ }^{71}$

The first decision issued in relation to austerity measures was Charalambous $v$ Republic. $^{72}$ The case concerned a 2011 law,73 obliging public officials, employees and pensioners to pay $2.5-3.5 \%$ of their monthly salary or pension as 'special contributions' for five years. ${ }^{74}$ The applicants (public officials and employees) claimed that their salary - an asset and

69 Other relevant case law relates to reductions of judges' remunerations and pensions, where these were found unconstitutional, in breach of Articles 158(3), 153(12) and the separation of powers; see Fylactou a.o. $v$ Republic (2013) 3 CLR 565.

70 See the Pancyprian Organization of Large Families a.o. v Attorney-General, App. No. 6914/12, 22 March 2017.

${ }^{71}$ It should be noted that the Administrative Court was established in January 2016, though the amendment of Article 146 of the Constitution (see the Eighth Amendment of the Constitution Law (Law No. 130(I)/2015) and the Establishment and Operation of an Administrative Court Law (Law No. 131(I)/2015)). Prior to this amendment all recourses were filed before the Supreme Court.

72 Joined cases nos 1480/2011 a.o. (11 June 2014).

73 Special Contribution for Officials, Employees and Pensioners of the Public Sector and Wider Public Sector Law $(112(\mathrm{I}) / 2011)$.

74 Special Contribution for Officials, Employees and Pensioners of the Public Sector and Wider Public Sector (Amending) Law (184(I)/2012). 
a property right - was unlawfully restricted in violation of the principle of equality (Article 28 of the Constitution), of tax equality (Article 24 of the Constitution), of the right to enter into a contract (Article 26) and of the right to property (Article 23 of the Constitution and Article 1 of the First Additional Protocol to the ECHR). The respondents submitted that the limitation was based on the grounds of public interest or public benefit, since the cuts were necessary and aimed at the reduction of public expenditures, in order to deal with the fiscal challenges of the Cypriot economy.

The majority decision of the Supreme Court rejected the application. First, the majority found no violation of the principle of equality, recognizing State discretion during such an exceptional crisis, in accordance with the ECtHR case law.75 Particularly, the majority held that the principle of equality must be balanced with the economic situation and fiscal policy in place at the time, and that the State has the discretion in times of extreme economic crisis to take measures targeting specific groups of the population (i.e., employees and pensioners of the public sector) without necessarily violating the principle of equal treatment. ${ }^{76}$ In relation to Article 26 , the Court very briefly mentioned that the said provision was not breached, since it guarantees the freedom to conclude a contract, not the rights created under the contract.

As for the right to property, the majority held, with an extensive reference to ECtHR case law, that it only applies to existing property. ${ }^{77}$ It may extend to the right to acquire property in the future, provided there is a pecuniary right that is legally enforceable for payment. In this sense, the civil servants' income or salary was found to constitute a property

75 Koufaki and ADEDY v Greece, Appl. Nos. 57665/12 and 57657/12, 7 May 2013; Andrejeva v Latvia [GC], no. 55707/oo, ECHR 2009.

76 See Constantinos Kombos and Stéphanie Laulhé Shaelou, "The Cypriot Constitution Under the Impact of EU Law: An Asymmetrical Formation," in National Constitutions in European and Global Governance: Democracy, Rights, the Rule of Law, eds. Anneli Albi, Samo Bardutzky (The Hague: Springer, 2019), 1396.

77 Marckx v Belgium, 13 June 1979, \$50 Series A no. 31; Vilho Eskelinen ao. v Finland [GC], no. 63235/00, \$45 ECHR 2007-II; Tushaj v Albania, App. No. 13620/10, [2013] ECHR 49, para. 21; Zelca a.o. v Romania, App. No. 65161/10, [2011] ECHR, para. 18. 
right protected under Article 23 of the Constitution; however, it did not guarantee any right to a salary of a particular amount. ${ }^{8}$ The majority further indicated that the right to property is not an absolute right, but may be limited for those reasons expressly provided in paragraph 3. Moreover, it recognized that Article 23(3) does not provide for a limitation of the right to property for consolidating the public finances as a ground of public benefit. 'Public benefit' in the context of Article 23(3) is clearly linked with the imposition of restrictions or limitations to the right to property for development and utilization purposes; it is not connected with the need to overcome an unprecedented crisis, as with the case under examination.

Nevertheless, the majority somewhat ambiguously proceeded to state that the relatively small special contribution rates of $2.5-3.5 \%$ of the monthly salary, did not amount to an arbitrary intervention to the right to property, as it did not neutralize the right nor affect the core of the right to a salary. Consequently, the applicants' argument that the special contribution violated Article 23 of the Constitution was also rejected by the Court. It is respectfully submitted that the Supreme Court erred in Charalambous. While the finding that the limitation of the right to property on the general grounds of public interest or benefit is not allowed under the Constitution stands correct, the subsequent examination of the effect of such impermissible constitutional limitation and the finding in favour of its constitutionality can only be described as controversial.79

Four months later, in Koutselini-Ioannidou $v$ Republic, ${ }^{80}$ the Supreme Court examined the constitutionality of another 2011 law, abolishing the

\footnotetext{
78 On this issue, the Court referred to the following ECtHR case law: Azinas v Cyprus, no. 56679/00, 20 June 2002; Koufaki and Adedy $v$ Greece, 57665/12 and 57657/12, 7 May 2013; Tushaj v Albania, App. No. 13620/10, [2013] ECHR 49, para. 21; Stummer v Austria [GC], no. 37452/02, \$82-83 ECHR 2011; Kanakis a.o. v Greece, no. 59142/00, 23 October 2003; Juhani Saarinen v Finland, Case No. 69136/01, 28 January 2003; Andrejeva v Latvia [GC], no. 55707/00, \$77 ECHR 2009; Stec a.o. $v$ the United Kingdom (dec.) [GC], nos. 65731/01 and 65900/01, ECHR 2005-X; Da Conceiçã Mateus and Santos Januário v Portugal, nos. 62235/12 and 57725/12, 8 October 2013; Valcov a.o. V Bulgaria, Appl. No. 2033/04, 8 March 2012, para. 84; Panfile v Romania, no. 1390/2011, 20 March 2012, paras. 15 and 18.

$79 \mathrm{Cf}$. the three dissenting judges' approach, who found the contested legislation in breach of Articles 23, 24, 26 and 28 of the Constitution.

8o Joined cases nos. 740/11 and others, 7 October 2014.
} 
phenomenon of multiple pensions and suspending the payment of pensions when a person reached the pensionable age, yet he/she continued to hold a public position or office. ${ }^{81}$ The applicants claimed that the said legislation breached Articles 23 and 28 of the Constitution, as well as Article 1 of the First Protocol. The respondents argued that the contested legislation did not result in the deprivation of property rights; rather, it was a temporary suspension. Alternatively, the respondents supported that if there was a deprivation of the right to property, it was justified on the ground of public interest or public benefit.

Regarding pension as a property right, the majority of the Supreme Court held that pensions are protected under Article 23 of the Constitution when the employer undertakes to pay a pension under their employment contract and once the person reaches the retirement age. ${ }^{82}$ The Supreme Court proceeded to analyze the relationship between Article 23 of the Constitution and Article 1 of the First Protocol, holding that the latter allows limitations on the ground of public interest, whereas the former does not. By referring to Charalambous, the Court reaffirmed that the limitation of the right to property on the ground of the development and utilization of property for the promotion of the public benefit, found in Article 23(3), is not identical but stricter than the limitation of the right on the ground of public interest, found in Article 1 of the First Protocol. Therefore, the Cypriot Constitution affords greater protection to the right to property than the ECHR and its First Protocol.

The majority ruled that the contested legislation did not amount to a mere suspension of the right, but essentially to the loss of the right to pension. Moreover, the limitations imposed to the right to property were based on the constitutionally impermissible grounds of public interest or public benefit. Thus, the majority found the contested legislation in

81 Pensions of State Officials (General Principles) Law (88(I)/2011).

82 This conclusion was based on Apostolakis $v$ Greece, on the opinions of several ECtHR judges in Azinas $v$ Cyprus, and on the Cypriot case law Filippou v Republic (2010) 3 CLR 241, Gregoriou v Republic (1992) 4 CLR 1239, Pavlou v Republic (2009) 3 CLR 584. 
breach of Article 23 and refrained from analyzing the violation of Article 28, having already found the legislation unconstitutional. ${ }^{83}$

Following these two decisions, the constitutional limitations to the right to property remained in ambiguity. The two approaches adopted by the Supreme Court in Charalambous, on the one hand, and KoutseliniIoannidou, on the other hand, resulted in two fundamentally different results for the protection of human rights. In Charalambous, the Court found that a 'public interest' or 'public benefit' limitation was not permissible under the Constitution; yet, the contested legislation was found constitutional since the reduction of the salary did not amount to a substantial or arbitrary intervention to the right to property. In Koutselini-Ioannidou, the Court implicitly formulated a two-step approach by first examining whether the limitation is permissible under Article 23(3) of the Constitution and then proceeding to examine the substance and legality of such limitation, only if the limitation is permissible. Unfortunately, the exact relationship between Charalambous/Koutselini-Ioannidou has not been explicitly resolved by courts.

Nevertheless, the subsequent case law of lower courts silently yields in favour of Koutselini-Ioannidou. In November 2018, the Administrative Court examined the constitutionality of pension reductions of public and wider public sector employees, by virtue of a 2012 law. ${ }^{84}$ Specifically, in Avgoustiv Republic, ${ }^{85}$ the applicants claimed that the contested restriction of the right to property was based on the impermissible ground of public interest, thus infringed Article 23(3) of the Constitution and Article 1 of the First Protocol. The Court applied the Koutselini-Ioannidou approach for assessing the constitutionality of the limitation of the right to property (including the right to pension) by examining the permissibility of the limitation under Article 23(3). The Court reaffirmed that limitations on property rights for the consolidation of public finances on the grounds of

\footnotetext{
${ }_{83}$ Cf. dissenting judges' opinion who found the legislation in conformity with the Constitution.

${ }^{84} \operatorname{Law} 168(\mathrm{I}) / 2012$.

${ }^{85}$ Avgousti a.o. v Republic, Joined Cases Nos 898/2013 a.0. (27 November 2018).
} 
public interest or public benefit are not permissible under Article 23(3). Thus, the Court did not proceed to examine the substance of such limitation and declared the relevant provisions unconstitutional. It is important to note that, the Republic appealed the decision of the Administrative Court due to its potentially catastrophic economic repercussions, and the appeal is awaiting adjudication.

On 29 March 2019, the Administrative Court issued three significant decisions on the constitutionality of laws imposing different forms of cuts and reforms to the salaries of employees of the public and wider public sector, with significant potential economic implications. In the first decision, Nicolaidi $v$ Republic, ${ }^{86}$ the Court was called to determine whether the 2012 legislative reductions in the salaries of the applicants (employees of the public and wider public sector) violated Article 23. ${ }^{87}$ The Administrative Court found that salaries fall within the definition of 'property' of Article 23 and, therefore, are constitutionally protected. The Court found the contested legislative provisions unconstitutional since the limitation imposed on the salaries of the applicants was justified on the grounds of public interest or public benefit, which are not permissible under the Constitution. Having found the provisions unconstitutional, the Court did not proceed to examine the rest of the claims of unconstitutionality based on Articles 9, 24, 26 and 28.

In Koundourou $v$ Republic, ${ }^{88}$ the second decision issued on the same day, the Administrative Court examined the constitutionality of the nonconcession of the indexation increases and increases in salaries until 2016,89 adopted on the ground of public interest in order to prevent any further deterioration of the public finances and to secure the correct functioning of the public service. The Court first affirmed that the increases in salaries and

86 Joint Cases Nos 98/2013 a.o. (29 March 2019).

87 Reduction in Remunerations and Pensions of Officials, Employees and Pensioners of the Public Service and of the Wider Public Sector Law (168(I)/2012). This was the same legislation assessed in Avgousti, but this case focused on salaries, rather than pensions.

88 Joint Cases Nos 611/2012 a.o. (29 March 2019).

89 Non-Concession of Increases in Salaries and of Indexation Increases of Officers and Employees' Salaries and of Pensioners' Pensions of the Public and Wider Public Sector Law (192(I)/2011). 
indexation increases are part of the employees' gross salary and fall within the definition of property. The failure of granting them on the ground of public interest constitutes an impermissible deprivation. Therefore, this legislation was also found unconstitutional. Finally, in Filippou $v$ Republic ${ }^{90}$ the Court examined the constitutionality of cuts of the gross salary of these employees, as a contribution to the Consolidated Fund of the Republic, ${ }^{91}$ with the aim of restraining the expenses of the public sector occupational pension scheme (GEPS). The Court held that the limitation of the right to property, which was also based on the ground of public interest, was not permissible under the Constitution. Thus, the amending law was deemed unconstitutional. ${ }^{92}$

In conclusion, these four recent decisions of the Administrative Court relating to the constitutionality of austerity measures reaffirmed that the approach of the legislature to adopt laws limiting the right to property of employees of the public and wider public sector on the grounds of public benefit or public interest was unconstitutional. In fear of having to compensate employees and pensioners of the public and wider public sector with more than two billion euros, the Republic filed appeals against Avgousti, Nicolaidi, Koundourou and Filippou. Thus, the constitutionality of these social protection cuts and reforms introduced through legislation to meet the strict conditionality requirements is at the time of writing still pending before the Supreme Court.

\subsubsection{The Right to Property: Constitutional vs. ECHR Protection}

The above analysis of the Cypriot case law in relation to austerity measures and their impact on the right to property demonstrates the willingness of the judiciary to bypass the pragmatist emergency approach in favour of a rights-based approach. In particular, the judicial approach

9o Joint Cases Nos 1713/2011 a.o. (29 March 2019).

91 Retirement Benefits for Employees in the Public and Wider Public Sector Law (113(I)/2011). This Law was abolished and replaced with the Retirement Benefits of Employees in the Public and Wider Public Sector, including the Local Authorities Law (Provisions of General Implementation) (216(I)/2012).

92 See also the relevant case law in Spiridaki v Republic, App No 830/2017 (28 June 20019), Petridi v Republic, App No 320/2015 (29 July 2019), which reaffirm Charalambous, Koutselini-loannidou, Avgousti and Nicolaidi. 
to this case law, with the exception of Charalambous, indicates that the national constitutional protection of the right to property can and should exceed that of the ECHR. ${ }^{93}$ This understanding was first reached in Koutselini-Ioannidou (although it was also briefly mentioned as obiter in Charalambous), where the Supreme Court explicitly stated:

"Article 23 of the Constitution provides greater protection than Article 1 of the First Protocol to the ECHR. While Article 1 allows for the restriction of property rights, for reasons of public benefit, Article 23(3) of the Constitution does not include the public interest or public benefit in the permissible grounds for limiting the right to property. [...] It is one thing to limit one's property right for public interest purposes (which is not provided for in Article 23) and another thing to limit one's right for the development and utilization of one's property to promote the public benefit (which is provided)." ${ }_{94}$

This abstract has been cited in all relevant subsequent case law.

This finding of the Supreme Court is indeed remarkable and is reinforced by Christodoulidou v Republic, ${ }^{95}$ where more than 200 applications were rejected due to the reliance on Article 1 of the First Protocol and the absence of a claim based on Article 23 of the Constitution. In particular, in Christodoulidou, the Administrative Court delivered its decision on the constitutionality of reductions and abolitions of shift and overtime allowances of 211 applicants working as firefighters, nurses and police officers. ${ }^{96}$ All applicants argued that these measures should be declared in breach of Articles 9, 24 and 28 of the Constitution, as well as Article 1 of the First Protocol. The failure to raise any claims on the grounds of Article 23 prohibited the Administrative Court from adjudicating on

93 For the approach of the ECtHR towards austerity measures, see loanna Pervou, "Human Rights in Times of Crisis: The Greek Cases before the ECtHR, Or the Polarisation of a Democratic Society," Cambridge Journal of International and Comparative Law 5, no. 1 (2016): 113-38; Nikolaos Papadopoulos, "Austerity Measures in Greece and Social Rights Protection under the European Social Charter: Comment on CSEE v. Greece Case, Complaint No. 111/2014, European Committee of Social Rights, 5 July 2017," European Labour Law Journal 10, no. 1 (2019) 85-97; Dimitrios Kagiaros, "Austerity Measures at the European Court of Human Rights: Can the Court Establish a Minimum of Welfare Provisions?," European Public Law 25, no. 4 (2019): 535-58.

94 Translation by the authors.

95 Christodoulidou a.o. v Republic, Joined Case Nos 441/2014 a.o. (12 November 2018).

96 The 2014 Budget Law (52(II)/2013). 
whether the contested legislation violated the constitutionally protected right to property.

When examining the alleged violation of Article 1 of the First Protocol, the Court held that the intervention to the right to property, through the reduction and abolition of allowances, was justified on the ground of public interest and was necessary and appropriate to achieve cost savings and a balanced budget for government expenditure. Additionally, the Court found that the $25 \%$ reduction in shift allowances and $33.3 \%$ in the overtime allowance was not a disproportionate restriction on their salaries as property rights, taking into account the financial benefit resulting from that restriction and the fact that a variety of other cuts in the salaries, allowances and pensions of all categories of civil servants and public pensioners ensured the saving of millions and reduced the budget deficit. As a result, the Court found that the reductions and abolition of specific allowances did not violate Article 1 of the First Protocol. ${ }^{97}$ It is submitted that if a claim were raised based on Article 23 of the Constitution, the outcome of this case would have been different.

In conclusion, the Supreme Court of Cyprus seems to have approached the different levels of domestic and international protection of human rights successfully (again with the exception of Charalambous, which can only be regarded as being decided per incuriam), in accordance with its constitutional and international duties. First, it complied with its responsibilities under Articles 33 and 35 of the Constitution and refused to subject the fundamental rights and liberties found in Part II of the Constitution to any other limitations or restrictions than those provided therein. Specifically, Article 33 envisages that fundamental rights and liberties guaranteed by Part II shall not be subjected to any other limitations or restrictions than those provided in the Constitution,

The Court also rejected the claim of violation of Article 9 as vague, general and without any evidence that would enable judicial review. For purposes of completeness, it should be noted that seven of the applications were successful on the basis of the principle of equality, due to the arbitrary distinction between nurses of the same category and the absence of any study justifying such distinction. 
whereas such limitations and restrictions shall be interpreted strictly and shall not be applied for any purpose other than those for which they have been prescribed. Article 35 imposes an imperative obligation to all State authorities and organs (legislative, executive and judicial) to respect, protect and fulfil the fundamental rights and liberties of Part II. Thus, the judiciary secured, within the limits of its competence, the efficient application of the provisions of Part II of the Constitution and complied with its own precedent by holding that Article 23 may only be restricted on the express basis of the Constitution..$^{8}$ Second, it complied with its international obligations deriving from Article 53 of the ECHR.99 Article 53 provides that the ECHR cannot be interpreted in such way as to limit or derogate from any of the fundamental rights and freedoms which may be ensured under the laws of the contracting parties. In other words, the ECHR establishes minimum standards, allowing national authorities to apply a higher level of protection. A higher level of protection which the Cypriot courts correctly applied, in the benefit of human rights protection.

\section{CONCLUSION}

In general, ESC rights have been present and active in the Cypriot legal order from the moment of its constitutional genesis and have been reinforced with Cyprus's participation in all significant international and regional instruments promoting and safeguarding the protection of ESC rights. The judiciary's approach towards the protection of the constitutionally envisaged ESC rights has always conformed with the approach of the ECtHR, due to the historical and unique connection that the Cypriot Constitution and the ECHR have had. The above analysis of ESC rights under the Constitution, such as the right to decent existence and social security (Article 9), the right to education (Article

$9^{8}$ See Aloupas v National Bank of Greece (1983) 1 CLR 55.

99 On Article 53 of the ECHR, see Catherine Van de Heyning, "No Place Like Home-Discretionary Space for the Domestic Protection of Fundamental Rights," in Human Rights Protection in the European Legal Order: The Interaction between the European and the National Courts, eds. Patricia Popelier, Catherine Van de Heyning and Piet Van Nuffel, (Cambridge: Intersentia, 2011), 65, 71-78. 
20), the right to join trade unions (Article 21(2)), the right to work (Articles 9 and 25), the right to strike (Article 27) and the right to property (Article 23), indicates the traditional interplay between domestic and external normative systems, as the judiciary has interpreted the constitutional text with recourse to comparative assessments and reliance on external influences (particularly on the ECHR and the ECtHR case law). However, the traditional streamlined approach and the reliance on external influences have shifted to a certain extent in favour of the domestic normative system and human rights protection (or at least in relation to the right of property), as a result of the detrimental social and economic consequences of the severe economic crisis that affected the island in an unprecedented manner.

This new approach of dismissing guidance from external influences and developing a purely domestic understanding of a constitutionally envisaged human right for the benefit of human rights protection was based on the idea that national constitutional protection can and should exceed that of the ECHR, by virtue of their different content and scope of respective limitations. Specifically, the Cypriot courts held that salaries, pensions and benefits of employees and pensioners of the public and wider public sector are safeguarded as property rights under Article 23 of the Constitution and Article 1 of the First Protocol to the ECHR. However, when assessing the permissibility of the cuts and reforms to salaries, pensions and benefits, the judiciary recognized that the right to property as envisaged in the Constitution affords greater protection than Article 1 of the First Protocol to the ECHR since the limitations imposed by the former provision are stricter. As a result, and regardless of the compatibility with the First Protocol to the ECHR of limitations imposed on the right to property on the rather general ground of public interest, such limitations are incompatible with the constitutional text, and thus the relevant legislation is null and void.

It is sincerely hoped that this rights-based approach will not be overturned by the upcoming final decisions of the Supreme Court on the pending appeals filed against Avgousti, Nicolaidi, Koundourou and Filippou, where the use of the 'police powers' of the State may be attempted to be used, as an exception 
clause allowing derogation from rights beyond those constitutionally provided, for reversing this new rights-oriented approach. ${ }^{100}$ Moreover, what is further at stake in the pending appeals is the compliance of Cypriot courts with their constitutional duty not to subject the fundamental rights and liberties found within the Constitution to any other limitations or restrictions than those provided therein and their compliance with their international obligation under Article 53 of the ECHR to use the treaty as setting minimum standards and not to interpret it in such way as to limit or derogate from any of the fundamental rights and freedoms which may be ensured under the laws of the contracting parties. Nevertheless, hoping that the approach is not reversed could prove to be mere wishful thinking.

\section{BIBLIOGRAPHY}

Ahmed, Tawhida and Israel de Jesús Butler. "The European Union and Human Rights: An International Law Perspective." European Journal of International Law 17, no. 4 (2006).

Alfredsson, Gudmundur. "Article 17." In The Universal Declaration of Human

Rights: A Commentary, edited by A. Eide, et al. 255-62. Oslo: Scandinavian University Press, 1993.

An-Na'im, Abdullahi Ahmed. "To Affirm the Full Human Rights Standing of Economic, Social and Cultural Rights." In Economic, Social and Cultural Rights in Practice: The Role of Judges in Implementing Economic, Social and Cultural Rights, edited by Yash Ghai and Jill Cottrell. 7-16. London: Interights, 2004. Bilchitz, David. "Socio-Economic Rights, Economic Crisis, and Legal Doctrine." International Journal of Constitutional Law 12, no. 3 (2014): 710-739.

De Smith, Stanley Alexander. The New Commonwealth and Its Constitutions. London: Stevens, 1964.

Douglas-Scott, Sionaidh. "The European Union and Human Rights after the Treaty of Lisbon." Human Rights Law Review 11, no. 4 (2011).

100 See Aloupas v National Bank of Greece (1983) 1 CLR 55. 
Emilianides, Achilles C. Constitutional Law in Cyprus. Alphen aan der Rijn: Wolter Kluwer Law and Business, 2013.

Golay, Christophe and Ioana Cismas. "Legal Opinion: The Right to Property from a Human Rights Perspective." Montreal: Rights and Democracy, 2010.

Howard-Hassmann, Rhoda E. "Reconsidering the Right to Own Property." Journal of Human Rights 12, no. 2 (2013).

Kagiaros, Dimitrios. "Austerity Measures at the European Court of Human Rights: Can the Court Establish a Minimum of Welfare Provisions?" European Public Law 25, no. 4 (2019).

Kombos, Constantinos and Stéphanie Laulhé Shaelou. "The Cypriot Constitution Under the Impact of EU Law: An Asymmetrical Formation." In National Constitutions in European and Global Governance: Democracy, Rights, the Rule of Law, edited by Albi, Anneli, Bardutzky, and Samo. 1373-1432. The Hague: Springer, 2019.

Kombos, Constantinos. "Constitutional Review and the Economic Crisis: In the Courts We Trust?" European Public Law 25, no. 1 (2019).

Kombos, Constantinos. "Constitutional Review and the Economic Crisis: In the Courts We Trust? - Part Two." European Public Law 25, no. 2 (2019).

Kombos, Constantinos. "Social Rights in the Republic of Cyprus." In Social and Economic Rights as Fundamental Rights, edited by Krzysztof Wojtyczek. 57-86. Utrecht: Eleven International Publishing, 2016.

Kombos, Constantinos. The Impact of EU Law on Cypriot Public Law. Athens: Sakkoulas, 2015.

Krause, Catarina and Gudmundur Alfredsson. "Article 17." In The Universal Declaration of Human Rights: A Common Standard of Achievement, edited by G. Alfredsson and A. Eide. 359-378. The Hague: Martinus Nijhoff, 1999. Kyriakou, Nikolas and Nurcan Kaya. "Minority Rights: Solutions to the Cyprus Conflict." A Report, Minority Rights Group International, 2011. 


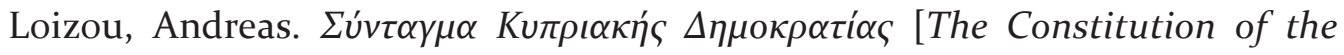
Republic of Cyprus]. Nicosia: 2001.

Markides, Alecos. “The Republic of Cyprus." In Constitutional Law of 10 EU Member States: The 2004 Enlargement, edited by C. Kortmann, et al. Deventer: Kluwer, 2006.

Papadopoulos, Nikolaos. "Austerity Measures in Greece and Social Rights Protection under the European Social Charter: Comment on CSEE v. Greece Case, Complaint No. 111/2014, European Committee of Social Rights, 5 July 2017." European Labour Law Journal 10, no. 1 (2019).

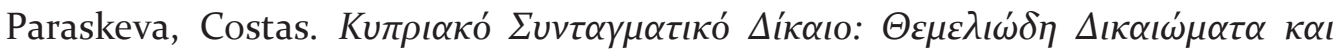

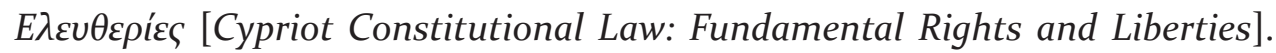
Athens: Nomiki Vivliothiki, 2015.

Pervou, Ioanna. "Human Rights in Times of Crisis: The Greek Cases before the ECtHR, or the Polarisation of a Democratic Society." Cambridge Journal of International and Comparative Law 5, no. 1 (2016).

Petrou, Panagiotis and Sotiris Vandoros. "Healthcare reforms in Cyprus 2013-2017:

Does the crisis mark the end of the healthcare sector as we know it?" Health Policy 122, no. 2 (2018).

Rosas, Allan. "Property Rights." In The Strength of Diversity: Human Rights and Pluralist Democracy, edited by Allan Rosas, Jan Helgesen, and D. Goodman. 133-157. The Hague: Martinus Nijhoff, 1992.

Ssenyonjo, Manisuli. Economic, Social and Cultural Rights in International Law. Oxford: Hart, 2009.

Tornaritis, Criton. "The Social and Economic Rights Under the Law of the Republic of Cyprus," in Mélanges Marcel Bridel (Lausanne: 1968).

Tornaritis, Criton. Cyprus and its Constitutional and Other Problems. Nicosia, 1980. Van de Heyning, Catherine. "No Place Like Home-Discretionary Space for the Domestic Protection of Fundamental Rights." In Human Rights Protection 
in the European Legal Order: The Interaction between the European and the National Courts, edited by Patricia Popelier, C. Van de Heyning, and P. Van Nuffel. 71-78. Cambridge: Intersentia, 2011.

Van Dooren, Machteld Inge. "The European Union and Human Rights: Past, Present, Future." Merkourios: Utrecht Journal of International and European Law 26, no. 70 (2009).

Vašák, Karel. "A Thirty-Year Struggle: The Sustained Efforts to Give Force of Law to The Universal Declaration of Human Rights." UNESCO Courier 11 (1977). 